\title{
The relationship between workload and fatigue level of laundry workers in Dalung Village, North Kuta District, Badung Regency
}

\author{
L G Evayanti $^{1 *}$, I G W Balikusuma ${ }^{1}$, S H Indonesiani ${ }^{1}$ \\ ${ }^{1}$ Faculty of Medicine and Health Sciences, Universitas Warmadewa, Denpasar, Bali \\ *luhgdeevayanti@gmail.com
}

\begin{abstract}
Laundry workers have various physical exertion and workload. However, fatigue level of them is not properly documented, especially in Dalung Village. The aim of this study is to determine the relationship between the workload and the fatigue level of laundry workers in Dalung Village, North Kuta District, Badung Regency. The design of this study was cross-sectional study. The subjects of this study were 40 laundry workers in Dalung Village, North Kuta District, Badung Regency and selected using purposive sampling (November - December 2017). Level of fatigue was measured using questionnaire by Suma'mur and then scored by Likert scale. Workload was measured through heart rate during exercise by pulsemeter. Data were analyzed by SPSS application using Somers'd test ( $\mathrm{p}$ value < 0.05). The result of this study is there was relationship between the workload and the fatigue level of laundry workers significantly ( $p<0.05 ; r=0.468$ ). This finding can be used for information of workload and health problems in laundry workers, especially in Dalung Village.
\end{abstract}

Keyword : Relationship, Laundry, Bandung Regency.

\section{Introduction}

Occupation is an important factor in human life. Various types of occupation have different of workloads and work duration. One of occupation option in Bali is laundry workers. Laundry workers have various tasks as follows: sorting, washing, drying, finishing, and distribution [1]. Since they have many different of tasks, the workload on them varies. Laundry workers are exposed to higher risk of fatigue and WMSD due to nature of their occupation [2]. Workload is proven as one of risk factors of work-related musculoskeletal disorders (WMSD) [3].

Everyone may experience levels of fatigue varying from mild to overwhelming at different times [4]. Fatigue can reduce worker's performance and life quality as well as increasing accident in the workplace [2,5]. Fatigue produces stress which is one of important factors in pathogenesis of serious illness. Rose et al. (2017) reported that fatigue was associated with severe medical diseases, health behavior and depression. Their study also shown that fatigue was significantly associated with work-related stress after statistically partialling out depression [6]. Fatigue can be a predictor of sickness absence. Based on previous study reported that fatigue is associated with short term and particularly with long term sickness absence [7]. Fatigue level of laundry workers is not properly documented in Bali, especially in Dalung Village. The aim of this study is to determine the relationship between the workload 
and the fatigue level of laundry workers in Dalung Village, North Kuta District, Badung Regency.

\section{Method}

The design of this study was cross-sectional study. The subjects of this study were 40 laundry workers in Dalung Village, North Kuta District, Badung Regency. They were selected using purposive sampling (November - December 2017). The characteristics of subjects such as age range, nutritional status, gender, heart rate during rest and work were shown in descriptive table. Level of fatigue was measured using questionnaire by Suma'mur and then scored by Likert scale. Workload was measured through heart rate during exercise by pulsemeter. Data were analyzed by SPSS application using Somers'd test $(\mathrm{p}<0.05)$.

\section{Results And Discussion}

The characteristics of subjects in in Dalung Village, North Kuta District, Badung Regency were shown in Table 1.

Table 1. Characteristics of subjects

\begin{tabular}{lcc}
\hline \multicolumn{1}{c}{ Parameters } & Frequency & Percentage \\
\hline Age range (years) & 19 & \\
$21-30$ & 11 & $47.5 \%$ \\
$31-40$ & 9 & 27.5 \\
$41-50$ & 1 & $22.5 \%$ \\
$51-60$ & & 2.5 \\
Gender & 3 & \\
Male & 37 & $7.5 \%$ \\
Female & & $92.5 \%$ \\
Nutritional status & 1 & \\
Underweight & 30 & $2.5 \%$ \\
Normal weight & 3 & $75 \%$ \\
Overweight & 6 & $7.5 \%$ \\
Obese & & $15 \%$ \\
Resting heart rate & & \\
(beats per minute) & 4 & $10 \%$ \\
51-60 & 36 & $90 \%$ \\
61-70 & & \\
Heart rate during & & \\
exercise (beats per minute) & 33 & $82.5 \%$ \\
$75-100$ & 7 & $17.5 \%$ \\
100-125 & & \\
Level of fatigue & 4 & $10 \%$ \\
Mild & 32 & \\
Moderate & 4 & \\
Severe & & \\
& & \\
\hline
\end{tabular}


In this study, the subjects is dominated by female (92.5\%), age range $21-30$ years $(47.5 \%)$, and normal weight $(75 \%)$. The highest heart rate is 66 beat per minute $(62.7 \pm 1.69)$ at rest and 113 beat per minute $(91,6 \pm 8.27)$ during exercise

Table 2. The relationship between workload and fatigue level of laundry workers

\begin{tabular}{clcccccc}
\hline & & \multicolumn{4}{c}{ Fatigue level } & p & \\
\cline { 2 - 5 } & & Mild & Moderate & Severe & Value & \multicolumn{1}{c}{$\mathbf{R}$} \\
\hline Heart rate during exercise & Mild (75-100) & 4 & 28 & 1 & & \\
(beats per minute) & Moderate (100-125) & 0 & 4 & 3 & 0.028 & 0.468 \\
\hline
\end{tabular}

Based on the result of this study there was positive relationship between the fatigue level and the workload of laundry workers significantly in Dalung Village, North Kuta District, Badung Regency ( $p<0.05, r=0.468$ ). The relationship between fatigue level and workload of laundry workers was shown in table 2

Fatigue is divided to peripheral and central fatigue. Peripheral fatigue is a reduction in the maximal muscle force or motor output. It is commonly due to overexertion, prolonged or strenuous physical activity. Central fatigue refers to tiredness, weakness, languor, or sleepiness. This may exist independently or may be due to some underlying psychological or pathological condition [4]. This study indicated that there was significant relationship between the workload and the fatigue level of laundry workers in Dalung Village, North Kuta District, Badung Regency $(p<0.05)$. Other studies shown that there were positive correlation between workload and fatigue level. The result of research on laundry workers in Warungboto Village, Umbulharjo District, Yogyakarta City shown that there was a relationship between workload and fatigue level [8]. Jayanti (2014) reported that workload on brick workers Jayanti had association with fatigue level in Keramasa Village, Blahbatuh District Kabupaten Gianyar Regency [9].

The factors that contribute to cause work-related musculoskeletal disorders might include non-ergonomic posture, repetitive motion, workload, and duration of work [5]. Laundry workers may do repetitive work. Lack of time for rest can increase level of fatigue [10]. Ekawati and Wahyuni (2018) reported that the laundry workers had long duration of working (15 hours each day) thus often complained WMSD on the region of neck, back, shoulder, waist, and hands [1]. Based on the previous study, there was a close relationship between musculoskeletal discomfort/pain and fatigue among workers [11,12].

Barth et al. (1976) found that physical fatigue reduces the willingness to exert effort in subsequent physical tasks [13]. Based on other study in 16 subjects reported that mental fatigue restricted the exercise tolerance through higher perception in efforts [14]. Fatigue can induce stress response. Indeed, chronic fatigue syndrome can increase hypothalamic-pituitaryadrenal axis disturbances so that there is increased of cortisol level and proinflammatory cytokines modulation $[15,16]$.

\section{Conclusions}

In summary, this study reported that workload had positive relationship between workload and fatigue level. Management on workload of laundry workers is required to improve the quality of working.

Acknowledgement 
The author has received the moral and emotional support of many colleagues at Faculty of Medicine and Health Science, Universitas Warmadewa, Bali.

\section{References}

[1] Ekawati and Wahyuni I 2015 The Influence of work posture to musculoskeletal dosprders pn laundry workers in Tembalang Region Proceedings International Seminar and Workshop on Public Health Action "Building Healthy Community (Semarang: Faculty of Health Sciences Dian Nuswantoro University)

[2] Putz-Anderson V, Bernard B P, Burt S E, Cole L L, Fairfield-Estill C, Fine L J, Grant K A, Gjessing C, Jenkins L, Hurrell J J, Nelson N, Pfirman D, Roberts R, Stetson D, HaringSweeney M, and Tanaka S 1997 Musculoskeletal disorders and workplace factors (Columbia: National Institute for Occupational Safety and Health)

[3] Shahriyani M, Latifi S M and Davood A 2018 Physical workload and musculoskeletal disroders in back, shoulders and neck among welders International Journal of Occupational Safety and Ergonomics p 1-18

[4] O'connell C and Stokes E K 2014 A Comprehensive Guide to Geriatric Rehabilitation (Churchill Livingstone)

[5] Yung and Marcus 2016 Fatigue at the Workplace: measurement and temporal development University of Waterloo: Ontario

[6] Rose D M, Seilder A, Latza U, Brahler E, Klein E M, Wiltlink J, Mischal M, Nickles S, Wild P S, Konjg J, Claus M, Letzel S, and Beutel M E 2017 Associations of Fatigue to Work-Related Stress, Mental and Physical Health in an Employed Community Sample BMC Psychiatry $17 \mathrm{p}$ 167

[7] Janssen N, Kant 1J, Swaen G M H, and Schroer C A P 2003 Fatigue as a Predictor of Sickness Absence: Results from the Maastricht Cohort Study on Fatigue at Work Occupational and Environmental Medicine 60 p i71-i76.

[8] MZ M W and Hariyono W 2013 Hubungan Antara Beban Kerja dengan Kelelahan Kerja Karyawan Laundry di Kelurahan Warungboto Kecamatan Umbulharjo Kota Yogyakarta Journal of Public Health 5(3)

[9] Jayanti 2014 Hubungan antara Beban Kerja dengan Kelelahan Kerja pada Perajin Batu Bata di Desa Keramasa Kecamatan Blahbatuh Kabupaten Gianyar (Denpasar: Fakultas Kedokteran dan Ilmu Kesehatan Universitas Warmadewa)

[10] Sudika 2016 Perbaikan Waktu Istirahat Penyetrika pada Perusahaan Laundry Made di Kerobokan Badung (Denpasar: ISI Denpasar)

[11] Chavalitsakulchai P and Shahnavaz H 1991 Musculoskeletal discomfort and feeling of fatigue among female professional workers: The need for ergonomics consideration J Hum Ergol 20(2) p 257-64

[12] Daneshamdi H, Choobineh A R, Ghaem H, Almand M and Fakherpour A 2017 The effect of musculoskeletal problem on fatigue and productivity of office personnel: a cross-sectional study J Prev Med Hyg 58 p E252-E258

[13] Barth J L, Holding D H and Stamford BA1976 Risk versus effort in the assessment of motor fatigue J Mot Behav 8 p 189-194

[14] Marcora S M, Staiano W and Manning V 2009 Mental fatigue impairs performance in humans Journal of Applied Physiology 106(3) p 857-864

[15] Hannibal K E and Bishop M D 2014 Chronic stress, cortisol dysfunction, and pain: A psychoneuroendocrine rationale for stress management in pain rehabilitation Phys Ther 94(12) p $1816-1825$ 
[16] Dedovic K Duchesne A Andrews J, Engert V and Pruessner J C 2009 The brain and the stress axis: the neural correlates of cortisol regulation in response to stress Neuroimage 47 p 864-871 